\title{
Мережко Е.Г. \\ Наблюдения за словообразовательной моделью в современных учебниках русского языка для начальных классов УМК «Начальная школа XXI века»
}

ФГБОУ ВО «СГУ им. Н.Г. Чернышевского» (Россия, Саратов)

doi: $10.18411 / \mathrm{lj}-07-2021-139$

\section{Аннотация}

В статье рассматривается актуальность наблюдений за словообразовательной моделью в процессе изучения морфемно-словообразовательной теории в начальной школе, представлена возможная классификация упражнений со словообразовательной моделью, проанализированы учебники русского языка для 2 класса УМК «Начальная школа XXI века» с точки зрения организации наблюдений за словообразовательной моделью.

Ключевые слова: словообразовательная модель, словообразовательные упражнения, морфемно-словообразовательная работа, словообразовательные наблюдения.

\section{Abstract}

The article considers the relevance of observations of the word-formation model in the process of studying morphemic-word-formation theory in primary school, presents a possible classification of exercises with a word-formation model, analyzes textbooks of the Russian language for the 2nd grade of the UMK "Elementary School of the 21 st century" from the point of view of the organization of observations of the word-formation model.

Keywords: word-formation model, word-formation exercises, morphemic-wordformation work, word-formation observations.

Морфемно-словообразовательная работа в начальных классах предусматривает организацию наблюдений младших школьников за словообразовательной структурой производных слов. Без этих наблюдений изучение только морфемного состава слова не позволит учащимся понять особенности русского словообразования, осознать словообразовательные процессы, семантико-словообразовательные связи между образованными друг от друга словами.

Анализ словообразовательной структуры производного слова включает не только проведение словообразовательного анализа, но и работу со словообразовательной моделью. Это позволит учащимся лучше усвоить способы словообразования, значения словообразовательных морфем. Через специальную систему словообразовательных упражнений необходимо показать младшим школьникам, что производные слова могут объединяться в группы по определенным признакам. Наблюдения за подобными группами слов, словообразовательными моделями демонстрируют младшим школьникам тот факт, что производные слова могут образовываться с помощью одних и тех же морфем (имеющих одно и то же словообразовательное значение и одну и ту же форму), одним и тем же способом словообразования, от слов одной и той же части речи. Такой системный подход к изучению словообразования, к обучению словообразовательному анализу, ознакомлению со способами словообразования, включающий работу со словообразовательными моделями, облегчит младшим школьникам усвоение элементов морфемно-словообразовательной теории, осознание словообразовательных понятий, их словообразовательную функцию, понимание того, как образуются в русском языке производные слова. 
Вместе с тем, не смотря на существенные изменения в содержании морфемнословообразовательной работы в современной начальной школе, словообразовательным моделям уделяется недостаточно внимания. Программа по русскому языку для начальной школы не предусматривает специального ознакомления младших школьников со словообразовательной моделью. Как правило, предлагаемые в учебниках и пособиях упражнения предусматривают лишь некоторые наблюдения за производными словами одной словообразовательной модели. Данные упражнения, в основном, представлены эпизодично, не системно и достаточно однообразны.

Вместе с тем работа со словообразовательной моделью может включать разнообразные наблюдения и задания. Например:

- Анализ производных слов одной словообразовательной модели

- Распределение слов на группы с учётом их принадлежности к той или иной словообразовательной модели

- Подбор слов одной словообразовательной модели

- Выделение из контекста слов указанной модели

- Анализ лексического значения слов на основе словообразовательной модели

- Наблюдение за употреблением слов определённых словообразовательных моделей в речи

и др.

Рассмотрим упражнения, представленные в современных учебниках русского языка для начальной школы.

Анализ учебников показал, что наиболее разнообразная словообразовательная работа, в том числе и со словообразовательной моделью, представлена в учебниках русского языка УМК «Начальная школа XXI века». Большая часть этих упражнений помещена в учебнике для 2 класса (2 часть), поскольку в соответствии с данной программой именно в этом классе изучается весь материал по составу слова и словообразованию.

Например, в упражнениях 1 (с.108, 2 класс, 2 часть), 1(с.110, 2 класс, 2 часть), 2 (с.112, 2 класс, 2 часть) 2 (с.118, 2 класс, 2 часть ) и др., учащиеся не только наблюдают за словообразовательной функцией суффиксов (приставок), их словообразовательным значением, но и за словами одной словообразовательной модели. Таким образом, младшие школьники, в сущности, на практической основе выделяют признаки производных слов одной словообразовательной модели. Вместе с тем, упражнения не предусматривают группировку, сравнение слов с учетом принадлежности их к той или иной словообразовательной модели.

В учебнике содержатся и упражнения на подбор (или образование) слов определенной словообразовательной модели (№2,3 с. 108-109, №1 с.117, №2,3 с.133134 и др.). Так, в упражнении №1 (с.110) слова одной словообразовательной модели уже выделены жирным шрифтом в тексте. Учащиеся должны указать, от каких слов и с помощью каких морфем образованы данные слова, определить значение суффикса, с помощью которого образована данная группа слов. Школьникам также предлагается подобрать слова рассматриваемой словообразовательной модели:

Прочитай басню.

Заяц и ёж

Беленький, гладенький заяц сказал ежу: «Какое у тебя, братец, некрасивое, колючее платье!» - «Правда, - отвечал еж, - но мои колючки спасают меня от зубов собаки и волка. Служит ли тебе также твоя хорошенькая шкурка?»

Зайчик вместо ответа только вздохнул. (К.Уиинский) 
Подумай, от каких слов образовались выделенные слова. Какое значение в них вносит суффикс -еньк-? Вспомни два-три слова с этим же суффиксом, запиши слова [1, c. 110-111].

В следующем упражнении учащимся на основе предложенного образца (по аналогии) предлагается образовать слова с помощью определенного суффикса. В сущности, школьники будут образовывать производные слова одной словообразовательной модели. Вместе с тем, значение суффикса не рассматривается, полноценного наблюдения за данной словообразовательной моделью не проводится:

Запиши слова парами по образцу. Обозначь суффикс -ость-.

Образец: щедрый - щедрость.

Вежливый, гибкий, ловкий, стойкий, усталый, смелый, жадный, нежный, честный, уверенный, осторожный, задумчивый [1, с. 131].

Особый интерес представляют упражнения, которые позволяют младшим школьникам осознанно различать суффиксы, совпадающие по своей форме, но отличные по значению, понять, что это разные суффиксы и слова, образованные с их помощью войдут в разные группы (слова разных словообразовательных моделей). Например:

Можно ли сказать, что в словах каждой группы один и тот же суффикс? Рассуждай так: «Чайник - это предмет, в котором кипятят или заваривают чай», «Школьник - это тот, кто учится в школе».

$\begin{array}{crcc}\text { 1) } & \text {-ник- } & \text {-ник- } \\ \text { чайник } & ? & \text { школьник } \\ \text { цветник } & ? & \text { дворник } \\ \text { 2) } & \text {-чик- } & \text { - чик- } \\ \text { барабанчик } & \text { летчик } \\ \text { карманчик } & ? & \text { перевозчик } \\ \text { 3) } & \text {-ик- } & \text {-ик- } \\ \text { котик } & ? & \text { химик } \\ \text { ротик } & ? & \text { умник } \\ 4) & \text {-арь- } & \text {-арь- } \\ \text { словарь } & ? & \text { пекарь } \\ \text { букварь } & ? & \text { вратарь [1, с. 128] } \\ \text { Вместе } & \text { с } & \text { тем, } & \text { не все возможности языкового материала упражнений }\end{array}$ реализованы с точки зрения работы со словообразовательной моделью. Так, на странице 120 учебника представлены слова одной словообразовательной модели, на материале которых учащиеся определяют особенности правописания суффиксов. К сожалению, собственно словообразовательные наблюдения, в частности, за словообразовательной моделью не предусмотрены:

Давай определим, когда пишется суффикс -ёнок-, а когда - -онок-. Обрати внимание на звуки перед суффиксами.

$\begin{array}{ll}\text { лосенок } & \text { медвежонок } \\ \text { теленок } & \text { мышонок } \\ \text { лисенок } & \text { галчонок } \\ \text { тигренок } & \text { бельчонок [ 1, с. 120] }\end{array}$

Таким образом, наблюдения за словообразовательной моделью являются важной частью морфемно-словообразовательной работы, способствуют освоению младшими школьниками словообразовательной функции и значения морфем, способов словообразования и обучению словообразовательному анализу производных слов. Упражнения со словообразовательными моделями могут быть более разнообразными 
(чем в учебниках русского языка для начальных классов) и способствовать решению лексико-словообразовательных задач.

1. Иванов С.В. и др. Русский язык: 2 класс: учебник для учащихся общеобразовательных учреждений: в 2 ч. Ч.2. - М.: Вентана - Граф, 2013.176 с.

\section{Мешкова И.В.}

Об отношении современной молодежи к ненормативной лексике

Нижнетагильский государственный сочиально-педагогический институт (филиал) ФГАОУ ВО «Российский государственный профессионально-педагогический университет»

(Россия, Нижний Тагил)

doi: $10.18411 / 1 j-07-2021-140$

\section{Аннотация}

В статье рассматривается проблема равнодушного отношения современной молодежи к широкому использованию ненормативной лексики в речи людей разного возраста. Представлены результаты анкетного опроса студентов педагогического вуза об их отношении к использованию ненормативной лексики. Выявлено, что $66 \%$ относятся с безразличием к употреблению нецензурных выражений друзьями, 27\% сочли возможным поддержать разговор с использованием таких слов.

Ключевые слова: ненормативная лексика, нецензурные выражения, молодежь, речевая культура.

\section{Abstract}

The article discusses the problem of indifference of modern youth to the widespread use of profanity in the speech of people of different ages. The results of a questionnaire survey of students of a pedagogical university about their attitude to the use of profanity are presented. It was revealed that $66 \%$ are indifferent to the use of obscene expressions by friends, $27 \%$ considered it possible to maintain a conversation using such words.

Keywords: profanity, obscene expressions, youth, speech culture.

Обращение к проблеме кризиса культуры устной русской речи, который выражается в повсеместном, часто открытом употреблении ненормативной лексики, обусловлено необходимостью формирования коммуникативной компетентности современного специалиста, осознанного отношения выпускника педагогического вуза к изучению причин использования детьми и взрослыми ненормативной лексики в существующих социокультурных условиях развития российского общества.

Культура речи может рассматриваться как часть общей культуры человека. В Большой российской энциклопедии понятие «культура речи» определяется как «владение нормами литературного языка в его устной и письменной форме, а также умение использовать выразительные средства языка в соответствии с целями и содержанием речи» [6]. Культура речи предполагает не только знание норм литературного языка, его выразительных возможностей и национальных особенностей, но и правильное отношение к тому, что именуется ненормативной лексикой [3, с. 306].

Ненормативная лексика (обсценная лексика) - сегмент бранной лексики различных языков, включающий грубейшие бранные выражения, часто выражающие спонтанную речевую реакцию на неожиданную (обычно неприятную) ситуацию [4].

Выделяют различные функции употребления обсценной лексики:

- повышение эмоциональности речи;

- разрядка психологического напряжения; 